\title{
Using City Branding as the Part of the Intersection Point of Modernization and Tradition. Case Study: Surakarta City (Solo), Indonesia
}

\author{
Eko Nursanty ${ }^{1,2, *}$, Joesron Alie Syahbana ${ }^{2}$, and Atik Suprapti ${ }^{2}$ \\ ${ }^{1}$ University of 17 Agustus 1945 Semarang, Indonesia \\ ${ }^{2}$ University of Dipenogoro, Indonesia
}

\begin{abstract}
To recognize a city is part of a city branding effort. By recognizing the dwelling, the city's inhabitants are able to create a spatial space in accordance with their easily recognizable cultural identity. In city branding, the memory of a city space is often the main ingredient in strengthening the identity. The efforts to use place making forces at this time are often used to solve the failures in multi-cultural spaces. Evolution in history is part of dynamic space planning as part of the identity of a city.The purpose of this research is to reveal the relationship between the formation of tradition spaces that are able to function in a modern way. The pattern of this relationship will produce spatial planning patterns with special characters as well. Humans as space users play a very big role as a space builder, where the decisions they make are often based on the tradition they have used for generations. The methods used in this study are qualitative, deductive using the theories that have been there before. Field research is used as empirical data in the form of interviews, photographs and field observations was conducted in various existing city spaces in Solo with the purpose to discover the existence of distinctive spatial patterns based on the typical behavior that has been passed down continuously as a result of the cultural process. The resulting discovery is a significant pattern of relationships between humans and their decision-making abilities in city space. This decision is based on self-awareness as part of the space they occupy. In a group, this awareness is part of the tradition's heritage that continues to develop in accordance with the human intellectual development.
\end{abstract}

Keywords: city branding, Surakarta, Solo, historical place, tradition place, urban heritage

\section{Introduction}

Major cities of the world are beginning to lose their ability to display their legal status at this time. Based on the existing laws, the cities no longer have special and separate powers. They follow the policies that have been determined by the government. Thus, the city managers attempt to translate the things that are still "unclear" from the delegated power (Frug, 1980).

The city becomes a productive region with its economic growth. It is not only a production center but also a distribution center and a collection center for local products. Furthermore, Frug's next research states that the history of city's growth illustrates how the city's freedom of opportunity develops itself through creative effort are the way to generate sustainable economic growth (Frug, 1999).

The world today has become a market system, where one city and another become a place to offer and sell its potential. Global growth means that every country, every city and every region must compete with one another and divide the world's consumers consisting of tourists, investors, students, entrepreneur, etc., with other countries that are also doing the same thing (Kotler, et al., 2010). The competitive ability of cities can be defined through several factors: the existing policies, the management institutions and the various strategies also processes that have been done. This will determine the level of sustainable productivity in a city, including economic, environmental and social issues (Eide, 2014).

The competitive ability of cities can be defined through several factors: the existing policies, the management institutions and the various strategies also processes that have been done. This will determine the level of sustainable productivity in a city, including economic, environmental and social issues (Anholt, 2007).

Because of the previous reasons, government and society need to find out what becomes the perception or picture of the world about their country, and then create a strategy to explore it. One of the keys to build a city's reputation is by describing itself openly, honestly, strongly, attractively, economically, socially and politically, also reflecting the spirit of local genius based on the aspirations of its people. The process and strategy to generate this positive reputation is by Branding effort in a city.

The quality of a brand in marketing is adding values to products and services in the invisible value form in order to win the existing market competition. It requires effort in extracting the values, which sometimes displays basic capabilities of the owner. It is easier to sell well-known products, rather than selling wholesale commodities or

Corresponding author: santy@untagsmg.ac.id 
general goods. Because people in general have understood that goods with certain quality are considered more valuable than those who do not or do not have a Brand (Anholt, 2005).

Still according to Anholt (2005), in the history of the world economy, many occurrences of a small country that looks unpromising, managed to become very rich. Meanwhile the country with a wide-scale and fertile land is not able to improve the ability to become a city that can improve its quality. Those are not able to improve the standards and qualifications of living for the inhabitants of the city. City space which owned in large quantities is unable to produce the quality of life that is dreamed by its citizens.

Various branding efforts today only become an element of the value of Brand made based on the wishes of the government. In some countries, city branding is only a universally applicable symbol. Brand should emphasize the invisible added value (intangible) on the product. In which this Brand is an effort of adding value so it will be higher or as an effort to ensure that the strength of Brand will last as long as the product exists.

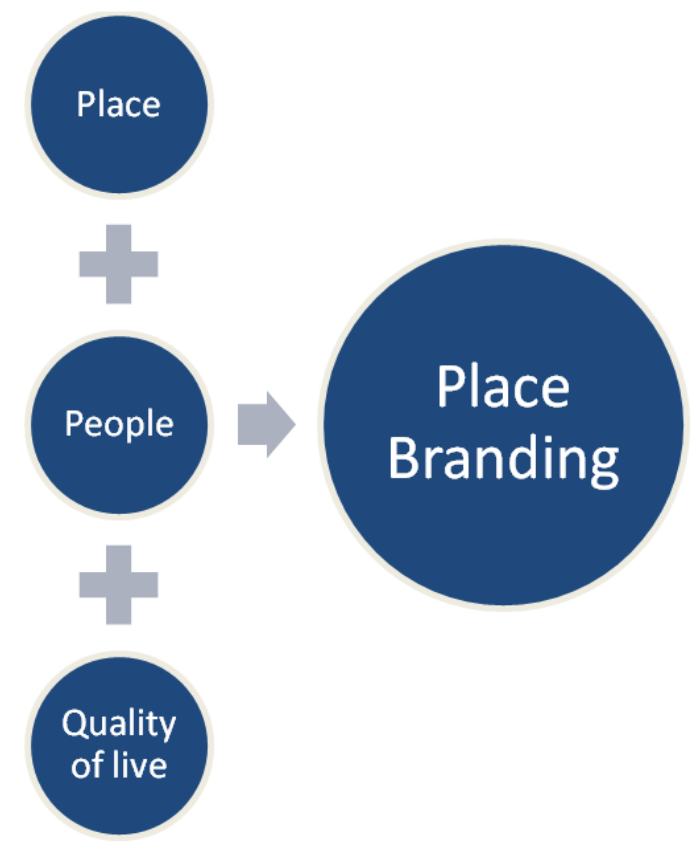

Fig. 1. Human and Qualified Space in Place Branding.

In Figure 1, it is shown that specifically in urban space; the most important element is the space user, in this case it is human who performs their activities in the urban spaces. The use of city space based on the concept of harmonization generates a good life quality; it can also give a good brand image in a city.

Meanwhile in the urban areas, which concerns the brand in the space and city is not only about communication but also about the policies and applications in it. The effort of this brand is done in relation that space or place also has the image as a product. These places depend heavily on the other things outside of itself as the power to create or improve those images for their progress and prosperity (Anholt, 2010).

Regional/spatial brands have several approaches in which enable increasing the speed, efficiency and effectiveness by using better imagery (Kotler \& Haider, 1993).

\section{City Competitive Advantage}

In the general marketing world, there are 5 strategies that can be done to win the competition in the development effort of a company, namely: First, A low-cost provider strategy appeals, it is a strategy from the consumer's perspective to choose low prices products or services. On the company, this is a strategy to find the steps to run a business at a low cost. Second, A broad Differentiation, it is to make differentiation efforts of product against products offered by the competitor company which is a step from the buyer's point of view, thus the level of difficulty for the opposing company to do the duplicate process needs to be sought. Third, A best cost provider strategy, it is a strategy given to the consumers by providing more value for the amount of money they have paid. The goal is to have a cheaper price and compete with opponent companies, but offering products that have superiority over the others. Fourth, A focused strategy which is based on the low cost concentration as a target segment of buyers and come out from the existing competition by serving buyers with certain skills that are lower than buyers from competing companies. Fifth, A focused (or market niche) strategy that is based on differentiating concentration efforts on the target buyer and come out of the opponent's competition by offering the consumer to choose their own necessities (Drucker, 1999). It is believed to be able to meet the tastes and needs of consumers than similar products produced by the opposite party (Swain, 2010). In a diagram, the five elements to win the competition in the business are illustrated in figure 2 below.

\section{low cost}

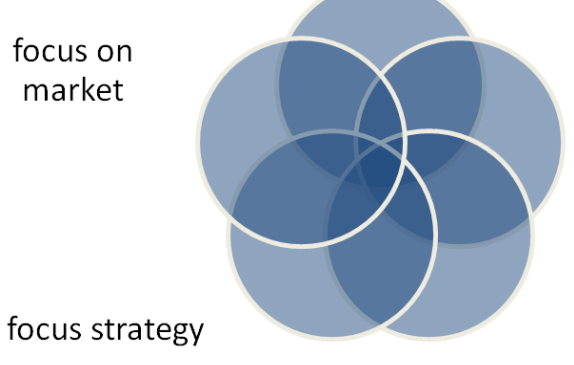

differentiation

Fig. 2. Strategy of Winning the Competition in the Business. Source: Kotler, processed by researcher, 2017.

Some of the above elements can also be applied for the development of the city's ability to compete with other cities around it, namely the element of Brand ability and human excellence in order to create a unique urban space.

Essentially, the planning cycle is nothing more than a logic activity that directs marketing planning and applies it regularly on marketing objects, including the city (Braun, 2008).

City branding is a new concept introduced by some marketing figures as an attempt to win a competition between countries and cities in the current global era. 
They argue that the struggle to get an attention for a brand is not limited to commercial goods and services, but applies equally to geo-political entities. Cities across the world are now competing to get income from various businesses, tourism and often tax sectors; sometimes this competition happens between one city and another. The supporters of City Branding's theory argue that a highly competitive environment becomes important for a space. It does not depend on its composition and size, but also to clarify the differences between them and convey its superiority. This is what they need to convey, which are the hidden values that are often called space branding (Anholt, 2005).

The implementation of the brand theory to the developing space on regional concepts such as country, district and city is starting to be considered important. It is now being realized that every city competes with other places to compete for markets, experts, investors, tourists, etc. The brand phenomenon in its initial space is an organic process of an organic process of a picture communication without strategy. City Branding is any activity aimed at transforming the city from an ordinary location into a destination. A successful Brand can transform the city into a place where people want to live, work and pay a visit to (Salman, 2008).

City Branding is very different from urban marketing. Urban marketing is a marketing theory that focuses on the consumer desires as the basic principles in conducting the operational process of an organization. Whereas in City branding, there are concerns about the chosen vision, mission and identity which play role in it. City Branding refers to the application of Branding techniques to geographic locations in a broad sense. It involves reputation, credibility, political power, security, comfort, etc. (Dinnie, 2008).

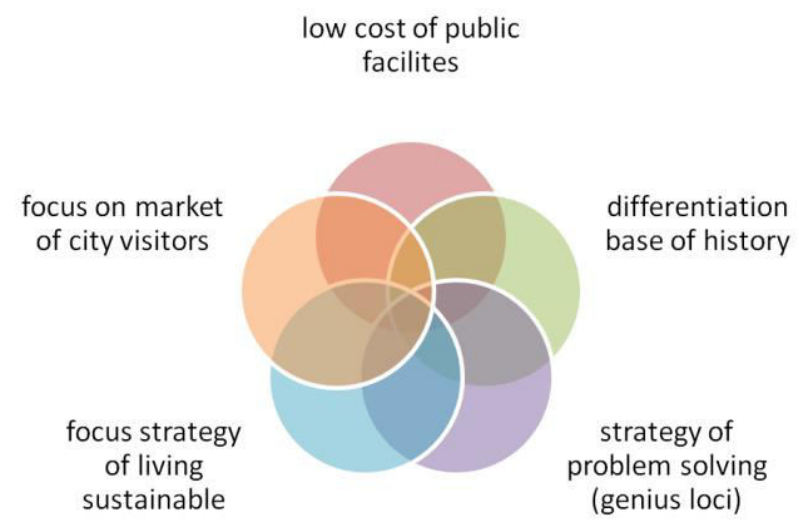

Fig. 3. Elements in Winning the City Competition.

Figure 3 illustrates the five elements to win the competition, which can also be done for a city. Although the city is not as production goods, but as

Thus, City Branding creates a picture of the city and more extensively on all that it offers and the interactions that occurs. From the consumer's point of view, a unique image is created in the city through all levels of interaction. City Branding is a valuable promise, a promise that keeps being maintained.

\section{Methods}

A brand, to be able to connect with human traits needs to attempt to build authentic DNA as a major marker that distinguishes it from others. This DNA will reflect the identity of a brand essential in the social network of its user community. Those brands that already have DNA will be able to build their sustainability character. The uniqueness that sets them apart from other brands has been understood by the consumers (Kotler, et al., 2010).

In the diagram, the research stages can be seen in the following Figure 4. Case Study in Solo City was observed starting from the human user space and the space itself. Through intense interaction for a long time, both of these elements produce a tradition space, modern and contemporary space.

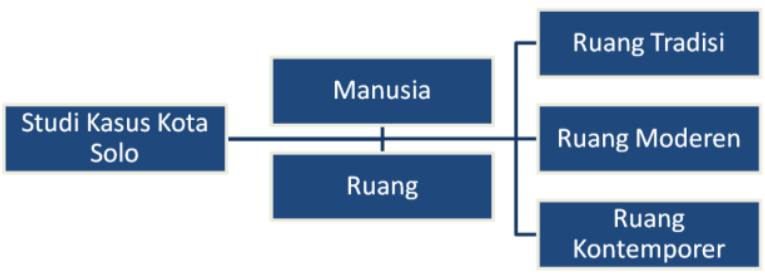

Fig. 4. Research Stages.

Furthermore, marketing researchers, especially for tourist destinations, need to understand the diversity of types and values contained in a place. This understanding will easily lead to an understanding of the essential character of each space, also known as space DNA. The authenticity of the brand space starts from the human. Learning the true identity can only be done through an understanding of the local people (Cuypers, 2016).

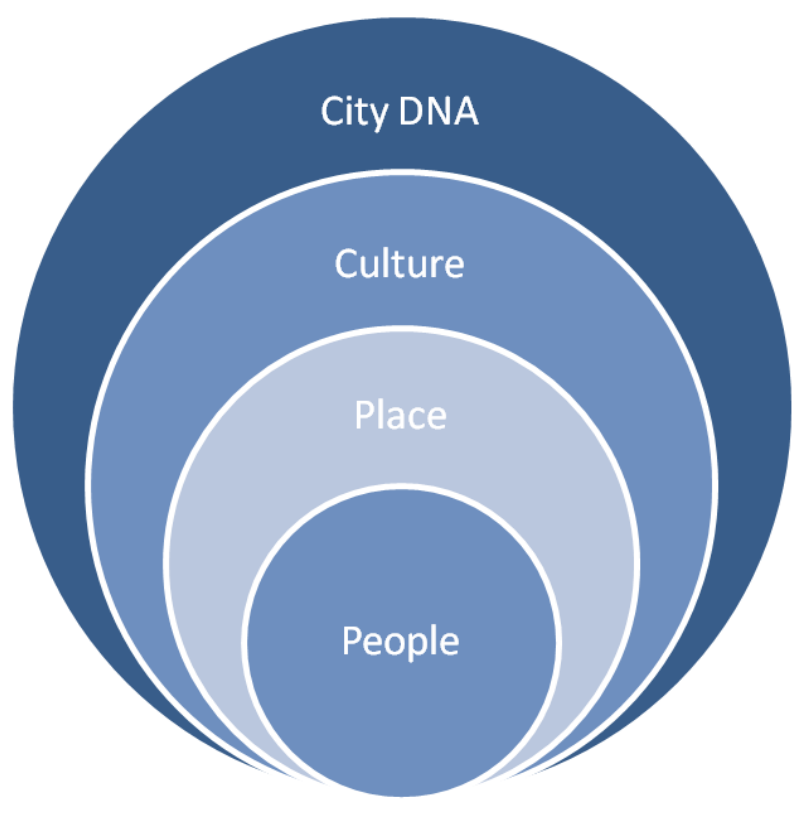

Fig. 5. Research Element Structure.

Figure 5 above describes the space DNA defined as the essential character. In the marketing of a city, it is often referred to as authenticity. A space is something tangible or real. It is a product which has consumptive meaning. Space 
brings all the needs of space for space consumers, such as tourists, visitors, citizens, investors and scientists, both students and researchers. In addition of having the ability to meet the needs of tangible or real space, a space also has an intangible or abstract value. For example, Paris is known as: city of light; city of mode; city of love. This is a way of describing the essence of DNA through the physical environment of a city.

At this time, many government of the city are beginning to find the importance of creating a brand for the place where they live. Citizens make a serious effort to create local culture in their city by owning and operating their local businesses. It can describe the personality of the said city (Hayden, 1997).

Both of community groups and decision makers protect valuable aspects of their city, such as historic areas, activities that have taken place for generations, and make their city even more attractive as a place to stay. The city's wealth and uniqueness are sources of inspiration from brand strategy that can illustrate a challenge or complexity. The city is expected to be able to use the specific factors combined into a distinctive framework, personality, history, values and composition of settlements as well as community's wealth (Florek, Insch, \& Gnoth, 2006).

City managers must understand the motives, expectations and needs both of their existing and potential residents; also ensuring their needs are fulfilled. A variety of personality and situational factors can influence the quality evaluation of the offered place and decrease the value of the place itself. The biggest challenge of City Branding is communicating different stakeholders into something united. Several cities in Indonesia have tried to capture the complexity that they have in a brand promise but failed. The effectiveness of city branding depends on the support and commitment of local elements such as communities, local businesses, government, and community groups. At the same time, City Branding must also be able to show more value to potential residents about the identity of the city.

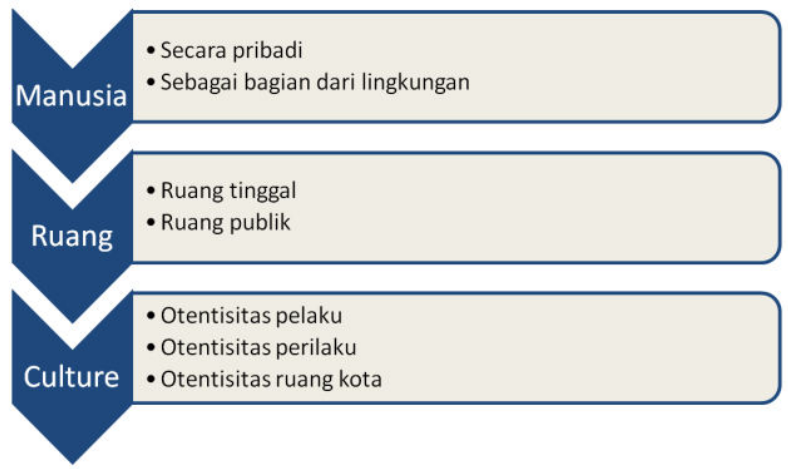

Fig. 6. Structure of Research Findings.

Figure 6 shows the structure of research finding. Human always behaves to maintain balance his daily life. Humans as individuals have the norms of developing themselves and their potential. Humans also structurally feel they are part of another human being around the community in their society and activity. On the outside of themselves and their society, humans also always keep harmony with the natural surroundings and believe they are part of the entire universe.

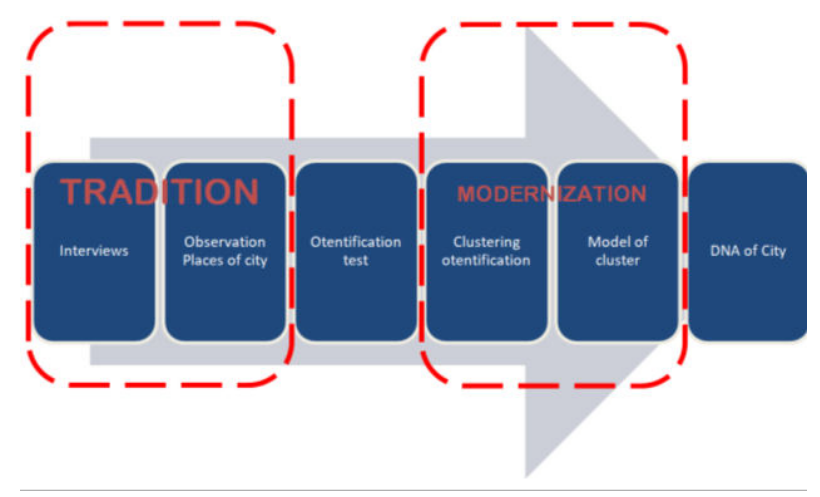

Fig. 7. Analysis Process of Research Findings.

In Figure 7 is the structure of research analysis which tradition process has existed since hundreds of years ago and developed into the modern era. The said process went through the existed process of authenticity. So that there are stages of change in accordance to the high and low level of authenticity owned.

\section{Result}

Surakarta (also called Solo or Sala) is a city located in the province of Central Java, Indonesia with 545,653 inhabitants and population of $12,390 / \mathrm{km}^{2}$.

This city has $44 \mathrm{~km}^{2}$ areas which adjacent to Karanganyar and Boyolali regencies in the north, Karanganyar and Sukoharjo regencies in the east and west, and Sukoharjo regency in the south. The east side of the city is passed by Bengawan Solo river. Together with Yogyakarta, Surakarta is the heir of the Mataram Kingdom which was broken down in 1755 .

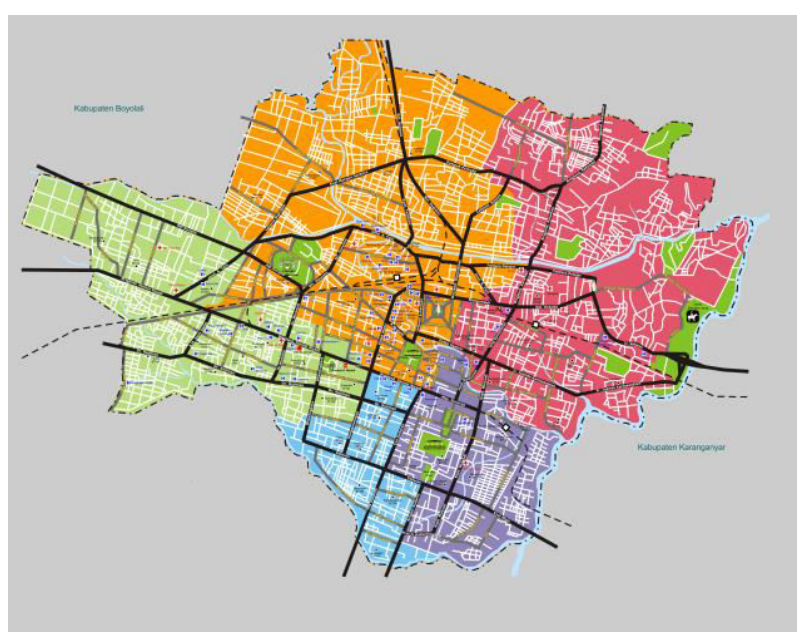

Fig. 8. Map of Surakarta City (Solo).

Source: Sumber: Solo Digital Map, 2010.

The current area of Surakarta city (Solo) can be described in the picture above, which consists of 5 districts and 51 subdistricts, as shown in Figure 8. Based on the following table in Figure 9, it is seen that the most crowded sub-district is Serengan Sub-district followed by Pasar Kliwon Sub-district, and Laweyan Sub-district as 3 of most crowded sub-districts among 5 districts in Kartasura. The location of this research 
was conducted in the 3 densely populated districts because they were the original regions of Surakarta (Solo).

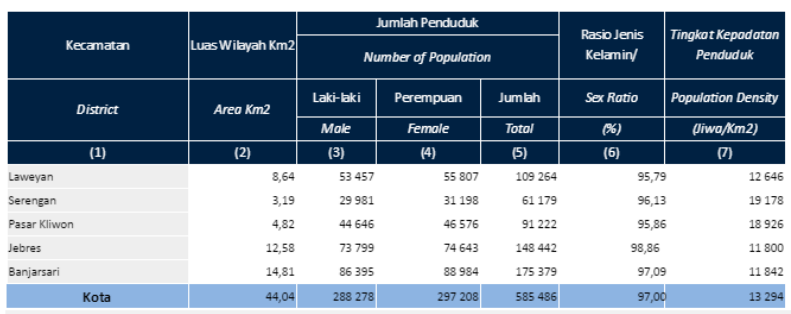

Fig. 9. Statistics Table of Density of Solo City Area.

Source: Department of Population of Surakarta, 2014.

Surakarta and its satellite cities (Kartasura, Solo Baru, Palur, Colomadu, Baki, Ngemplak) are mutually integrated areas called Solo Raya. Solo Raya is unique because the area of Surakarta city is only $44 \mathrm{Km}^{2}$ and surrounded by its buffer cities, each of which is approximately half the size of Surakarta city and directly adjacent to form a unified central city area. The total area of Surakarta City and its buffer areas are currently about $150 \mathrm{~km}^{2}$ with population about 1 million people.

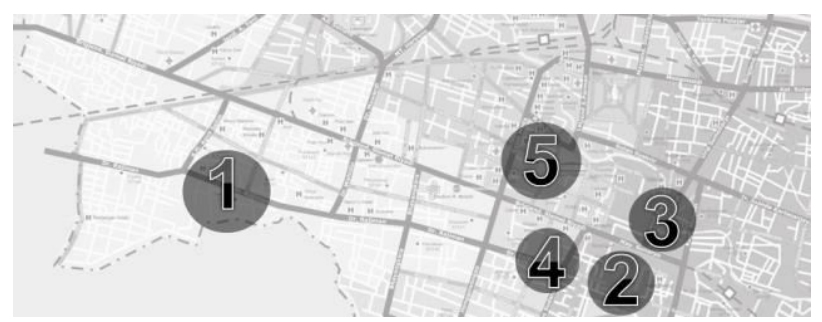

Fig. 10. Elements of Solo Heritage Room.

In figure 10 above, there are about the 5 elements of heritage space in Solo city found based on the preferences of tourists, namely: (1). Kampung Batik Laweyan; (2). Mangkunegaran Palace; (3). Kampung Batik Kauman; (4) Klewer Traditional Market and (5). Mangkunegaran Palace.

Based on the preferences of tourists, two groups of dominant space zones were also found as follows: Zone A is a heritage zone and zone $\mathrm{B}$ is a zone that is considered to represent modern symbols.

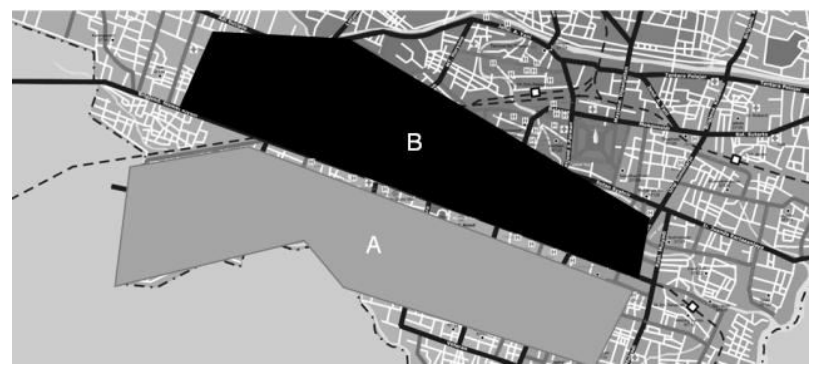

Fig. 11. Two magnetic symbols of the Space of Solo City.

\section{Discussion}

The centers of kingdoms in Java could only grow because they had favorable geographical factors. These geographical factors enable them to develop economic base of agrarian and trading, which in turn conquered other areas. The capital of the ancient kingdom of Java is always based on the concept of macrocosm and microcosm (Handinoto, 2015).

If cultural symbols get farther away from the center, those symbols will be weaker. However, there is often a counter-culture that emerges in the midst of subjects, which comes from their collective unconscious mentalities. Mangkunegara's position, which was closer to the axis, made using access to the Vastenberg Fortress, produced several recognizable symbols closer to the European symbol. These can be seen by the existence of Mangkunegara military tradition (Kuntowijoyo, 2016).

The following Figure 12 illustrates the structure of findings of space authenticity. In which there are elements of the efforts of the city to do city branding to its city as follows: Modern spaces consist of economic space. Contemporary spaces consist of public spaces. Contemporary space has a modern form but accommodate the activities of tradition which firmly rooted by the community. Meanwhile settlement is a part of space that is considered able to describe the integrity of the authenticity of space, be it through tangible or intangible.

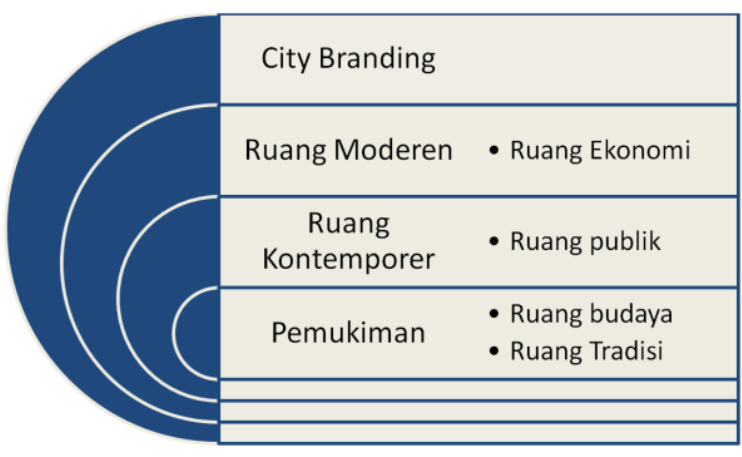

Fig. 12. Struktur Temuan Otentisitas Fungsi Ruang Heritage Kota Solo.

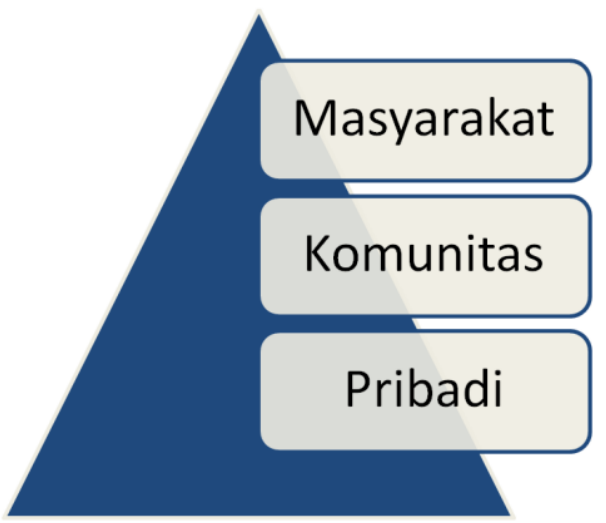

Fig. 13. Findings Structure of the Authenticity of Solo City Heritage Room Function.

Figure 13 illustrates the findings structure of the heritage city space users based on interviews with tourists. Tourists who travel freely and privately occupy the highest number in the pyramid. The second position of most tourists is those who come in groups of the community. They generally have an interest in similar travel types and city space. Meanwhile 
the public chose the tourist space on the amount and location of more specific types and amounts.

The following Figure 14 illustrates the zonation of the previous Figure 13. The findings structure of urban space users with self-contained tourism character occupies the largest urban space in zone C. Meanwhile the next urban space user is the community who occupies zone B in Figure 14. The last space user in which the user group is the local community, the preferred tourist space is the zone A.

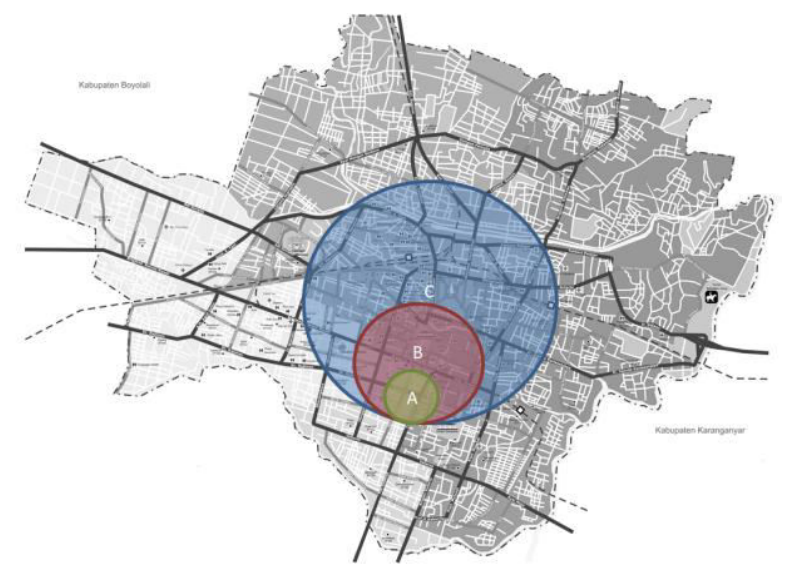

Fig. 14. Structure of Hierarchy Authenticity Public Space of Solo Heritage.

\section{Conclusion}

The encounter between heritage city space and modern urban space always generates a unique combination for a city. The uniqueness of the composition is analogous to the DNA of the city. Recognizing the city's DNA is able to provide a clearer understanding of the uniqueness of the city. In the end, the uniqueness of a city will give strengthening branding efforts to the city.

A city which has been identified by the DNA of its city, has grown and transformed into a modern city but has never lost its form and identity of both space users and the urban spaces in which people are located and interacting with each other.

The composition of all city elements in varying degrees of created authenticity creates a force for the city to be able to compete with the other cities around it. It is able to survive the stages of authenticity it has. Although the city changes according to the needs of the development of the era, the parts of the city still have the value of authenticity structurally that forms the ability to compete for the said city.

\section{References}

Anholt, S., 2005. Brand New Justice How branding places and products can help the developing world. Burlington: Elsevier Butterworth-Heinemann.

Anholt, S., 2007. Competitive Identity. The New Brand Management for Nations, Cities and Regions. New York: Palgrace Macmillan.

Anholt, S., 2010. Places Identity, Image and Reputation. London: Palgrace Macmillan.
Braun, E., 2008. City Marketing Towards an Integrated Approach. Rotterdam: Erasmus University.

Dinnie, K., 2008. Nation Branding. Concepts, Issues and Practice. Burlington: Elsevier.

Drucker, P., 1999. Management Challange. Burlington: Elsevier.

Eide, E. B., 2014. A report of the Global Agenda Council on Competitiveness, The Competitiveness of Cities. Swiss: World Economic Forum.

Frug, G. E., 1980. The City as a Legal Concept. Harvard Law Review, 93(6), pp. 1057-1154.

Frug, G. E., 1999. City Making. Building communities without building walls. Jersey, United Kingdom: Princeton University Press. 